\title{
Volume VI - Article 2 \\ Escaping Davy Jones' Locker: How the Motion Picture Industry Can Stop Digital Piracy Without Unnecessary Litigation
}

\author{
Robert H. Wright ${ }^{1}$
}

Fall 2005

\section{Copyright (C) University of Pittsburgh School of Law Journal of Technology Law and Policy}

Contrary to popular belief, motion picture piracy is not a modern phenomenon. ${ }^{2}$ Indeed, Hollywood studios have been engaged in a continuous battle against pirates ever since theatres began showing films in the late nineteenth century. ${ }^{3}$ One of the earliest methods of motion picture piracy, for example, was the "bicycling of prints," a practice by which a theatre operator would literally transport film reels between multiple theatres by bicycle to avoid the cost of licensing reels for each. ${ }^{4}$ With the advent of the Internet, however, the rate of motion picture piracy has increased exponentially. While truly measuring the extent of such illegal activity is impossible, recent estimates by the Motion Picture Association of America ("MPAA") suggest that somewhere between 300,000 and 350,000 motion pictures are illegally downloaded from the

\footnotetext{
${ }^{1}$ Franklin Pierce Law Center, LL.M. (2004); Louis D. Brandeis School of Law at the University of Louisville; J.D. (2003), Centre College; B.A. (2000). As is everything I do, this Article is for Julia.

${ }^{2}$ See Kerry Segrave, Piracy in the Motion Picture Industry (McFarland \& Company) (2003).

${ }^{3}$ See id.

${ }^{4}$ See Bernard R. Sorkin, A Geriatric View of Motion Picture Piracy, 51 J. COPYRIGHT SOC'Y U.S.A. 237, 237 (2003).
} 
Internet every day. ${ }^{5}$ With Hollywood studios already losing four billion dollars in potential profits each year to analog piracy, ${ }^{6}$ the continuous growth of digital piracy threatens the very existence of the motion picture industry. It is no surprise, then, that industry trade organizations like the MPAA are now feverishly searching for an effective way to address the problems posed by digital piracy.

The purpose of this article is to offer the motion picture industry a solution to these problems. Part I begins with a discussion of the three recent technological advancements DeCSS, DivX, and increased access to broadband technology - which have made digital motion picture piracy possible. Part I also considers the common methods used by digital pirates to duplicate motion pictures and to distribute them to others over the Internet. Part II addresses the framework of legal protection provided by the Copyright Act of 1976 ("Copyright Act"), the No Electronic Theft Act ("NET Act"), ${ }^{8}$ and the Digital Millennium Copyright Act ("DMCA"), 9 which can be invoked by the motion picture industry to pursue legal recourse against digital pirates. Finally, Part III concludes by arguing against the invocation of any of these three acts, since the problem of digital motion picture piracy is simply too widespread for piecemeal litigation to effectively address the problem. Instead, Part III contends that digital motion picture piracy is a problem best addressed by eliminating the need and/or desire of digital pirates to commit such unlawful acts and suggests several ways in which this end might be achieved.

\footnotetext{
${ }^{5}$ Matthew C. Mousley, Note, Peer-to-Peer Combat: The Entertainment Industry's Arsenal in its War on Digital Piracy, 48 Vill. L. Rev. 667, 674 (2003).

${ }^{6}$ Motion Picture Association of America, Anti-Piracy, at $<$ http://www.mpaa.org/anti-piracy/content.htm $>$ (last visited August 7, 2004).

${ }^{7} 17$ U.S.C. $\S \S 101-1332(2000)$.

${ }^{8} 17$ U.S.C. $\S 506$ (a) (2000).

${ }^{9}$ Digital Millennium Copyright Act of 1998, Pub. L. No. 105-304, 112 Stat. 2860.
} 


\section{Digital Motion Picture Piracy}

\section{A. Overcoming Initial Barriers}

The Internet has not always been a viable means for illegally distributing motion pictures. ${ }^{10}$ Indeed, until recently the size of digital motion picture files alone made their widespread distribution over the Internet impractical, if not entirely impossible. ${ }^{11}$ Unlike an MP3, a relatively small digital music file that can be downloaded in a matter of minutes over even the slowest of Internet connections, the file resulting from digitizing a motion picture is extraordinarily large. ${ }^{12}$ Fairly recently, when the hard drives of most personal computers were less than ten gigabytes in size, storage of such large files was impossible without the removal of other necessary files from the system. ${ }^{13}$ Even users who possessed drive space large enough to store a digital motion picture were deterred from doing so by the amount of time that transferring such a file over a traditional dial-up Internet connection would consume. ${ }^{14}$ These impracticalities forced most digital pirates to focus their efforts on downloading music rather than motion pictures. ${ }^{15}$ Soon, however, technology evolutions all but eliminated these hurdles,

\footnotetext{
${ }^{10}$ See John Pantages, Avast Ye, Hollywood! Digital Motion Picture Piracy Comes of Age, 15 Transnat'L Law.
} 155-61 (2002) (noting the various reasons why motion pictures were "relatively insulated" from digital piracy).

${ }^{11}$ See id. at 161-62 (explaining that before motion pictures were able to be compressed, it would take nearly six hours of uninterrupted download time in order to transfer the file using even the fastest of Internet connections). ${ }^{12} I d$.

${ }^{13}$ S.E. Oross, Fighting the Phantom Menace: The Motion Picture Industry's Struggle to Protect Itself Against Digital Piracy, 2 VAnD. J. ENT. L. \& PRAC. 149, 150 (2000). Motion Picture Association of America President Jack Velenti contented that "[c]urrently our films are protected by two factors - the amount of time needed to download a full-length motion picture and the lack of unprotected digital copies of our works." Id.

${ }^{14}$ Jeremy Paul Sirota, Note, Analog to Digital: Harnessing Peer Computing, 55 HASTINGS L.J. 759, 764-65 (2004) (noting the decline in music sales attributed to an increase in illegal file sharing).

${ }^{15}$ Mousley, supra note 4, at 162-68. 
namely through the decryption of CSS, the development of DivX, and an increase in residential broadband connectivity. ${ }^{16}$

\section{DeCSS}

To prevent their unlawful reproduction, DVDs are protected by Content Scramble System ("CSS"), "an encryption-based security and authentication system that requires the use of appropriately configured hardware ... to decrypt, unscramble and play back, but not copy, motion pictures on DVDs." "17 Confidence in CSS's capacity to prevent motion picture piracy has "facilitated enormous growth in the use of DVDs for the distribution of copyrighted movies to consumers." 18 The motion picture industry's vision of a piracy-free world, however, proved to be short lived when a Norwegian teenager named Jon Johansen quickly bypassed the protection afforded by CSS. ${ }^{19}$ Johansen, along with two other unidentified individuals, reverse-engineered the technology of a licensed DVD player and culled from it the information necessary to decrypt $\mathrm{CSS}^{20}$ Using this information, Johansen developed DeCSS, a decryption program which allows users to transfer the motion picture file stored on a DVD to a computer's hard drive. ${ }^{21}$ Once the

\footnotetext{
${ }^{16}$ See Universal City Studios, Inc. v. Reimerdes, 82 F. Supp. 2d 211 (S.D.N.Y. 2000); see also Pantages, supra note 10 , at $163-66$.

${ }^{17}$ Reimerdes, 82 F. Supp. $2 \mathrm{~d}$ at 214.

${ }^{18}$ As the court noted in Universal Studios v. Reimerdes,

DVD movies first were introduced in the United States in 1996. Over 4,000 motion pictures now have been released in that format in the United States, and movies are being issued on DVDs at the rate of over 40 new titles per month in addition to rereleases of classic films. More than 5 million DVD players have

Id. been sold, and DVD disc sales now exceed one million units per week.

${ }^{19}$ Universal City Studios, Inc. v. Reimerdes, 111 F. Supp. 2d 294, 311 (S.D.N.Y 2000); see Pantages, supra note 10, at 163 .

${ }^{20}$ Universal City Studios, Inc. v. Corley, 273 F.3d 429, 437 (2d Cir. 2001).

${ }^{21}$ Reimerdes, 111 F. Supp. 2d at 311; see Pantages, supra note 10, at 163.
} 
film is stored on the hard drive, it can be "played on a non-CSS-compliant player and copied, manipulated, and transferred just like any other computer file., ${ }^{22}$

Anxious to share his achievement with others, Johansen posted the executable object code for DeCSS on his personal website. ${ }^{23}$ News of the program spread quickly and within months of its initial appearance online, DeCSS "was widely available on the Internet in both object code and various forms of source code. ${ }^{24}$ With the ability to duplicate a DVD now available to anyone with access to the Internet, a new age of digital piracy was inevitable. The motion picture industry, however, was quick to take action. In order to prevent the further spread of DeCSS, several Hollywood studios sent cease-and-desist letters to the owners of many of the websites posting or linking to Johansen's program. ${ }^{25}$ Ultimately, after only a few of the individuals to whom letters were sent removed DeCSS from their website, ${ }^{26}$ Universal Studios, on behalf of eight other motion picture studios, filed suit under the Digital Millennium Copyright Act against several of the website owners. ${ }^{27}$ Although Universal Studios eventually succeeded in its case, the lengthy court battle exacerbated the problem of digital piracy by calling even more attention to the availability of DeCSS. ${ }^{28}$

\section{2. $\operatorname{Div} X$}

\footnotetext{
${ }^{22}$ Corley, 273 F.3d at 437-38.

${ }^{23}$ Reimerdes, 111 F. Supp. 2d at 311; see Pantages, supra note 10, at 163-64.

${ }^{24}$ Corley, 273 F.3d at 439.

${ }^{25}$ Reimerdes, 111 F. Supp. 2d at 312.

${ }^{26} I d$.

${ }^{27}$ E.g., id.

${ }^{28}$ See id.; see also Pantages, supra note 10, at 164.
} 
DeCSS made digital motion picture piracy possible. ${ }^{29}$ The practicedid not gain widespread popularity, however, until the subsequent development of DivX. ${ }^{30}$ The brainchild of a French video engineer nicknamed "Gej" and a German computer hacker known as "Max Morice," ${ }^{31}$ the DivX computer program reduces the five gigabytes of data typically stored on a DVD into a substantially smaller file with little or no loss in quality. ${ }^{32}$ Once a DVD source has been compressed and synchronized with DivX, a user only needs to install a free, downloadable file called a codec into a media player to view the motion picture file on his personal computer. ${ }^{33}$ On its own, DivX would have had little impact on digital motion picture piracy. ${ }^{34}$ However, when coupled with DeCSS, the program created for the first time a viable platform for widespread motion picture piracy. ${ }^{35}$ As the district court noted in Universal Studios, " [ i $]$ t is entirely feasible to decrypt a DVD with DeCSS, compress and synchronize it with DivX, and then make as many copies as one wishes by burning the resulting files onto writeable CD-Roms, which are sold blank for about a dollar a piece." 36

\footnotetext{
${ }^{29}$ Pantages, supra note 10, at 164-66.

${ }^{30} I d$.

${ }^{31} I d$.

${ }^{32}$ Reimerdes, 111 F. Supp. $2 d$ at 313. (noting that a "decrypted [DVD] file is very large - approximately 4.3 to 6 GB or more depending upon the length of the film - and thus extremely cumbersome to transfer or store on portable storage media").

${ }^{33}$ Pantages, supra note 10, at 164-65.

${ }^{34}$ See id. at 165 . This assumption is based upon the statements of Jack Valenti, president of the Motion Picture Association of America, who has previously stated in regards to DivX, "We're not against the new technology. We're against new technology used illegitimately. And DivX is compression technology. There's nothing illegal about it ...." Id.

${ }^{35} I d$.

${ }^{36}$ Reimerdes, 111 F. Supp. 2d at 314; see Pantages, supra note 10, at 166.
} 


\section{Increased Broadband Connectivity}

Even with the successful developments of DeCSS and DivX, digital piracy would not be as great of a concern today were it not for the recent increase in residential broadband connectivity. ${ }^{37}$ Residential Internet users have traditionally accessed the World Wide Web through dial-up services, which transfer data at a rate of approximately fifty-six kilobytes per second. ${ }^{38}$ Transferring a motion picture file at this rate of speed requires anywhere between twelve and twenty-four hours of uninterrupted download time. ${ }^{39}$ Broadband alternatives such as DSL and cable, however, offer much quicker rates of data transfer, enabling one to download a motion picture file from the Internet in a little over two hours. ${ }^{40}$ Given the speed with which residential broadband users are able to download such large files, it is therefore not surprising that they are twice as likely as those with a traditional dial-up connection to attempt to download a motion picture file from the Internet. ${ }^{41}$ Moreover, residential broadband users are three to four times more likely than their dial-up counterparts to download motion picture files on a regular basis. $^{42}$

These statistics are understandably alarming for the motion picture industry. An even greater concern to Hollywood studios, however, is the rate at which residential Internet users are

\footnotetext{
${ }^{37}$ Pantages, supra note 10, at 165.

${ }^{38} I d$.

${ }^{39}$ See Melissa Perenson, Insecure Seas, Hollywood Reporter, Sept. 25, 2000, at 2000 WL 25250501; see also Pantages, supra note 10, at 165-66.

${ }^{40}$ See supra note 39.

${ }^{41}$ See Michael Pastore, American Users Ready for High Speed Access, ClickZ Broadband Internet Statistics, at http://www.clickz.com/stats/markets/broadband/article.php/10099_307031 (last visited Oct. 6, 2004); see also Pantages, supra note 9, at 165-66.

${ }^{42}$ See Pastore, supra note 41; see also Pantages, supra note 9, at 165-66.
} 
replacing their dial-up connections with broadband alternatives. ${ }^{43}$ In 1998, only three-tenths of a percent of residential Internet users accessed the World Wide Web through a broadband connection. ${ }^{44}$ With the decreasing cost of broadband connectivity, more residential Internet users have replaced their dial-up connections with faster, more efficient broadband alternatives such as DSL and cable services. ${ }^{45}$ For example, a recent study conducted by the Pew Internet and American Life Project found that forty-eight million residential Internet users are currently accessing the World Wide Web through some form of high-speed Internet connection. ${ }^{46} \mathrm{~A}$ similar study conducted by the Nielson/NetRatings company found that the number of residential broadband users increased fifty-nine percent between December 2001 and December $2002 .^{47}$ Given the dramatic increase in the use of high-speed Internet connections and the corresponding surge in illegal downloading of motion picture files, it is only a matter of time before digital motion picture piracy becomes as widespread as music piracy on the Internet.

\footnotetext{
${ }^{43}$ See Pantages, supra note 10, at 165-6.

${ }^{44} I d$. at 165.

${ }^{45}$ See Michael Pastore, American Users Ready for High Speed Access, ClickZ Broadband Internet Statistics, at http://www.clickz.com/stats/markets/broadband/article.php/10099_307031 (last visited Oct. 6, 2004); see also Pantages, supra note 9, at 165-6.

${ }^{46}$ The Pew Internet \& Am. Life Project, 55\% of Adult Internet Users Have Broadband at Home or Work (April 2004), available at http://www.pewinternet.org/pdfs/PIP_Broadband04.DataMemo.pdf (on file with the on file with the Pittsburgh Journal of Technology Law and Policy), cited in Tim Wu, When Code Isn't Law, 89 VA. L. REV. 679, 725 (2003).

${ }^{47}$ See Neilson/Netratings, Broadband Access Grows 59 Percent, While Narrowband Use Declines, According to Nielsen/Netratings, available at www.nielsen-netratings.com/pr/pr_030115.pdf (last visited Oct. 6, 2004).
} 


\section{B. One Remaining Barrier}

As a result of DeCSS, DivX, and an increase in residential broadband connectivity, motion picture piracy is now "push button easy." "48 However, even with the ability to copy a DVD and to effectively distribute it to others in a matter of minutes, perpetrators of digital motion picture piracy remain hindered by the lack of a single, reliable source from which they can download a motion picture. ${ }^{49}$ That is, the already inherently difficult task of locating a specific motion picture file in the vastness of cyberspace is further complicated by the many avenues which a digital pirate might need to pursue in order to do so. ${ }^{50}$ The most popular method of pirating a motion picture is through the use of a peer-to-peer file sharing network. ${ }^{51}$ Although these networks vary greatly by name, they are modeled on either one of two methods of distribution: the Napster-method and the Kazaa-method. ${ }^{52}$ In addition to peer-to-peer networking, a motion picture might be pirated over the Internet with the help of a "charitable pirate," the use of a digital storage web service, or via e-mail, bulletin boards, and online chat services. ${ }^{53}$ While these alternatives are less popular than peer-to-peer networks, each is a far more efficient means of distributing a pirated motion picture, in large part because they rely on person-to-person interaction rather than person-to-search engine interaction. ${ }^{54}$

\footnotetext{
${ }^{48}$ Doris Estelle Long, E-Business Solutions to Internet Piracy: A Practical Guide, 740 PLI/Pat 769, 781 (2003).

${ }^{50}$ See id. at 767-77 (explaining the various ways in which digital piracy generally occurs).

${ }^{51} I d$. at 777 (noting that the use of peer-to-peer file sharing networks is the way in which software, films, and music is most often pirated).

${ }^{52} I d$.

${ }^{53}$ See id. at 776.

${ }^{54}$ These alternatives are discussed in greater detail in supra sub-part 2.
} 


\section{Peer-to-Peer File Sharing Networks}

Based upon the concepts underlying the development of ARPANET and USENET, peerto-peer file sharing networks are the result of "multiple interactive devices acting both as clients and as servers. ${ }^{, 55}$ The most well-recognized of these networks is Napster, which, at the height its popularity, hosted to tens of millions of active users. ${ }^{56}$ Ironically, however, Napster was not a true peer-to-peer network, but instead was a hybrid network combining the elements of a clientserver network with those of a peer-to-peer network. Napster users became "peers" in that each had the ability to request copyrighted material from, and to provide the same material to, others accessing the network. Before material could be transferred between users, the request was first processed by a central server owned and operated by Napster and was then directed to a user with the requested material stored on his computer. ${ }^{57}$ The result effectuated a faster, more efficient transfer of material between users. ${ }^{58}$ Ultimately, though, the degree of control that Napster retained over the process of transferring copyrighted material between users led to the network's demise. ${ }^{59}$ In 2002, after suit was filed against it by several record companies for copyright infringement, Napster was shut down.

\footnotetext{
${ }^{55}$ Sirota, supra note 14 , at 761.

${ }^{56} \mathrm{Wu}$, supra note 46, at 728 .

${ }^{57}$ David J. Colletti, Jr., Technology Under Seige: Peer-to-Peer Technology is the Victim of the Entertainment Industry's Misguided Attack, 71 GEO. WASH. L. REV. 255, 264 (2003) (noting that the function of a Napster's central server is consistent not with a true peer-to-peer network, but rather with a more traditional client-server model).

${ }^{58} \mathrm{Wu}$, supra note 46, at 728 (explaining that "the Napster server facilitated both database searching and brokering of individual connections").

${ }^{59}$ See A \& M Records, Inc. v. Napster, Inc., 284 F.3d 1091 (9th Cir. 2002).
} 
In the post-Napster world, peer-to-peer network designers have almost entirely abandoned use of the client-server elements which doomed Napster. ${ }^{60}$ The most well-known example of more recent peer-to-peer networks is the FastTrack network designed by Dutch computer programmers Nikalas Zennstrom and Janus Friis. ${ }^{61}$ Accessible through client applications such as Kazaa and Morpheus, the FastTrack network, like Napster, operates with a partial dependence upon several centralized server functions. ${ }^{62}$ Indeed, a central server on the FastTrack network maintains user registrations, grants access to the network, and facilitates the search for other users currently logged into the network. ${ }^{63}$ Unlike the Napster network, however, transfer of material over the FastTrack network is solely dependent upon the ability of a user's computer to efficiently catalog files, to send and receive download requests, and to route incoming and outgoing data. ${ }^{64}$ To date, systems operating with such decentralized architecture have avoided liability under United States copyright law. Nonetheless, the ultimate viability of the FastTrack network remains to be seen.

\section{Charitable Pirates}

Just as Jon Johansen posted DeCSS on his website simply to disseminate the program over the Internet, many digital pirates similarly make their motion picture files accessible to others at little or no cost. ${ }^{65}$ Characterized as "charitable pirates" by one commentator, these

\footnotetext{
${ }^{60}$ See Wu, supra note 46, at 734 (noting that "[t]he results are programs of great sophistication, attuned carefully to the doctrine of copyright").

${ }^{61} \mathrm{Id}$.

${ }^{62} I d$.

${ }^{63} \mathrm{Wu}$, supra note 46 , at 735 .

${ }^{64}$ Id.; see Sirota, supra note 14, at 761-62.

${ }^{65}$ See Long, supra note 48, at 776.
} 
individuals seek no real financial gain from their pirating activities. ${ }^{66}$ Instead, charitable pirates are moved by a sense of altruism toward the greater online community as a whole. ${ }^{67}$ Most often, the charitable pirate is a college or university student whose motion picture files are made accessible only to others sharing the campus' local area network. ${ }^{68}$ Those who are more brazen and are willing to risk the possible legal implications of unlawfully supplying others with a pirated motion picture, however, are likely to link their files to a website so that they can be downloaded by anyone accessing the Internet regardless of their physical proximity to the student's college or university. ${ }^{69}$ Such websites are rare, and even those which do exist are difficult to locate without being told of their existence firsthand..$^{70}$ Once found, though, they are a highly efficient means of distributing pirated motion pictures.

\section{Message Boards, E-Mail, and Instant Messaging Programs}

Another way in which a motion picture might be digitally pirated is through the use of email, message boards, and chat services. ${ }^{71}$ These types of web-based communication facilitate digital piracy by allowing those who wish to trade or sell pirated motion pictures to contact others interested in doing the same. ${ }^{72}$ For example, a fan of George Lucas' "Star Wars" franchise might discuss the films' characters and plot lines with others on a message board

\footnotetext{
${ }^{66} I d$. Charitable pirates "give the works away for free (hence the 'charitable' nature of their activities. Of course the works they are so willing to give away do not belong to them. Hence the 'pirate"').

${ }^{67} I d$.

${ }^{68} I d$.

${ }^{69}$ See id.

${ }^{70}$ Pantages, supra note 10, at 166 (noting that downloading motion pictures "requires using some of the lesser known parts of the Internet, including FTP file sharing and IRC chat channels or 'secret' web sites which are beyond the expertise of the average Internet user.")

${ }^{71}$ Long, supra note 48 , at 778 .

${ }^{72} I d$.
} 
devoted to the franchise or to science-fiction films in general. If the fan was interested in obtaining a DivX copy of one of the "Stars Wars" films, all he would need to do is post a message on the board soliciting a trade or sale. Given the number of users generally visiting such message boards and the ease with which a DVD is "DivX'd," it is likely that the fan would receive a reply. Once terms of the agreement have been reached, the DivX file can then be easily transferred either as an e-mail attachment or directly over an instant messaging program such as AOL Instant Messenger. ${ }^{73}$ Such discreet transfers are advantageous for digital pirates, as it is virtually undetectable by law enforcement authorities.

\section{United States Copyright Law}

Article I, Section 8 of the United States Constitution provides that "[t]he Congress shall have the Power ... To promote the Progress of Science and useful Arts, by securing for limited Times to Authors and Inventors the exclusive Right to their respective Writings and Discoveries." ${ }^{, 74}$ Acting pursuant to this authority, Congress has enacted three statutes which make it unlawful to reproduce a motion picture and distribute it to others without first obtaining the author's consent: the Copyright Act, ${ }^{75}$ the NET Act ${ }^{76}$, and the DMCA ${ }^{77}$ Prior to the advent of the Internet, the Copyright Act provided a reasonably effective deterrent against motion picture piracy. ${ }^{78}$ The Copyright Act was ill-equipped, however, to deal with the problem of

\footnotetext{
${ }^{73} I d$. at $778-79$.

${ }^{74}$ U.S. CONST. art. I, $\S 8$, cl. $1,8$.

${ }^{75} 17$ U.S.C. $\S 105$, et seq. (2000).

${ }^{76} 17$ U.S.C. $\S 506(\mathrm{a})$ (2000).

${ }^{77}$ Digital Millennium Copyright Act, 17 U.S.C. $§ 1201$, et seq. (2000).

${ }^{78}$ Oross, supra note 13, at 154 (explaining that "profitless piracy" was unable to be sufficiently addressed by the Copyright Act because it required the intent to profit financially as an element of a criminal action for willful infringement).
} 
digital motion picture piracy. ${ }^{79}$ To bring United States copyright law "squarely into the digital age," ${ }^{80}$ Congress passed the NET Act and subsequently the DMCA. $\quad{ }^{81}$ The former merely amended the Copyright Act to criminalize digital motion picture piracy. ${ }^{82}$ The DMCA, on the other hand, created an entirely new cause of action for digital motion picture piracy. ${ }^{83}$

\section{A. The Copyright Act}

Enacted with the intent of establishing a uniform standard of protection for both published and unpublished works, ${ }^{84}$ the Copyright Act protects an artist's rights in all "original works of authorship fixed in any tangible medium of expression, now known or later developed, from which they can be perceived, reproduced, or otherwise communicated, either directly or with the aid of a machine or device." ${ }^{85}$ Those protected rights include an artist's right to reproduce, adapt, distribute, perform, and display his work. An artist's work is "fixed" within the meaning of the Copyright Act when "its embodiment in a copy or phonorecord, by or under the authority of the author, is sufficiently permanent or stable to permit it to be perceived, reproduced, or otherwise communicated for a period of more than transitory duration." ${ }^{, 86}$ Where these rights have been "violated" by another, the owner may bring an action for infringement

\footnotetext{
${ }^{79}$ See id.

${ }^{80}$ S. ReP. No. 105-190, at 1 (1998); see also Peter Moore, Steal This Disk: Copy Protection, Consumers' Rights, and the Digital Millennium Copyright Act, 97 Nw. U. L. REv. 1437, 1437-38 (2003).

${ }^{81}$ See S. REP. No. 105-90, at 1; see also Moore, supra note 79, at 1437 (stating that the DMCA contains numerous anticircumvention provisions that served to revise the Copyright Act).

${ }^{82}$ Oross, supra note 13 , at 154.

${ }^{83}$ See Digital Millennium Copyright Act, 17 U.S.C. $\$ 1201$, et seq. (2000).

${ }^{84}$ See Mousely, supra note 5, at 675 (stating that the Copyright Act preempts most state common law and statutory protection).

${ }^{85} 17$ U.S.C. $\$ 102$ (a) (2000).

${ }^{86} 17$ U.S.C. § 101 (2000).
} 
under $\S 501$ of the Copyright Act. ${ }^{87}$ More specifically, $\S 501(\mathrm{~b})$ provides that "[ $\left.\mathrm{t}\right] \mathrm{he}$ legal or beneficial owner of an exclusive right under a copyright is entitled ... to institute an action for any infringement of that particular right committed while he or she is the owner of it." ${ }^{\prime 88}$

Those found to be in violation of the Copyright Act are subject to a variety of civil and criminal penalties. ${ }^{89}$ Section 502 , for example, allows courts to "grant temporary and final injunctions on such terms as it may deem reasonable to prevent or restrain [further] infringement of a copyright. ${ }^{, 90}$ Section 503 further extends the court's powers in equity to allow it to impound allegedly infringing articles during the time an action is pending ${ }^{91}$ and to destroy or otherwise dispose of infringing material "[a]s part of a final judgment or decree ...."92 For plaintiffs uninterested in the equitable remedies provided by $\S \S 502$ and 503, monetary damages are available under $\S 504$ in the amount of "the copyright owner's actual damages and any additional profits of the infringer", ${ }^{93}$ or statutory damages are available "in a sum of not less than $\$ 750$ or more than $\$ 30,000 .{ }^{" 94}$ The most stringent punishment available under the Copyright Act, however, is the criminal penalty set forth in 18 U.S.C. $\S 2319$. Under that section, anyone who willfully infringes another's copyright is subject to not more than one year in prison. ${ }^{95}$

\footnotetext{
${ }^{87}$ See 17 U.S.C. $\$ 501$ (2000).

${ }^{88} 17$ U.S.C. $\S 501$ (b) (2000).

${ }^{89}$ See 17 U.S.C. $\S \S 502-504$ (2000); see also 18 U.S.C. $§ 2319$ (2000).

${ }^{90} 17$ U.S.C. $\S 502(a)(2000)$.

${ }^{91} 17$ U.S.C. § 503(a) (2000).

9217 U.S.C. $\S 503(\mathrm{~b})(2000)$.

${ }^{93} 17$ U.S.C. $\$ 504(\mathrm{a})(1)(2000)$.

${ }^{94} 17$ U.S.C. $\S 504(c)(1)$ (2000). Note, however, that if the court finds "that infringement was committed willfully," an award of statutory damages may be increased "to a sum of not more than $\$ 150,000$." 17 U.S.C. $\S 504(c)(2)$ (2000)

${ }^{95}$ See 18 U.S.C. § 2319(b)(3) (2000).
} 
Those who do so repeatedly may receive a prison sentence of "not more than 10 years" depending upon the extent and duration of their infringement. ${ }^{96}$

Despite these remedies, the Copyright Act is not weighted entirely in favor of artists. To balance the rights of the artist to the fruits of his efforts with the rights of the general public in appreciating the artist's work, the Copyright Act provides various limitations on its general prohibition against infringement. ${ }^{97}$ For example, $\S 107$ of the Copyright Act allows for the unauthorized "fair use" of an artist's work by the general public. "98 "Fair use," as defined by the Copyright Act, includes "use by reproduction ... for purposes of criticism, comment, news reporting, teaching (including multiple copies for classroom use), scholarship, or research." 99 This list of fair use "purposes" is not exhaustive, and whether use of an artist's work constitutes "fair use" such that it will survive an action for infringement is determined in each particular case. ${ }^{100}$ When making such a determination, four factors are considered: (1) the purpose and character of the use, (2) the nature of the copyrighted work, (3) the amount and substantiality of the portion used in relation to the copyrighted work as a whole, and (4) the effect of the use upon the potential market for or value of the copyrighted work. ${ }^{101}$

B. The No Electronic Theft Act

The civil and criminal penalties available under the Copyright Act provided the motion picture industry with adequate recourse against those pirates using traditional analog means to

\footnotetext{
${ }^{96}$ See 18 U.S.C. $\S 2319(b)(2)(2000)$.

${ }^{97}$ See 17 U.S.C. § 107 (2000); 17 U.S.C. § 109 (2000); 17 U.S.C. § 302(a) (2000).

${ }^{98}$ See 17 U.S.C. $\$ 107$ (2000).

${ }^{99} \mathrm{Id}$.

${ }^{100}$ See L. A. Westermann Co. v. Dispatch Printing Co., 249 U.S. 100, 104 (1919).

${ }^{101}$ See 17 U.S.C. $§ 107$ (2000).
} 
illegally reproduce and distribute their films. ${ }^{102}$ Nevertheless, as evolving Internet-based technology transformed the Internet into a viable means of distributing motion pictures to others, movie studios soon realized that the Copyright Act did little to address the growing threat posed by digital pirates. ${ }^{103}$ Under pressure from the MPAA, Congress passed the NET Act. The NET Act amended the Copyright Act to criminalize, among other things, "the reproduction or distribution, including by electronic means, during any 180-day period, of 1 or more copies or phonorecords of 1 or more copyrighted works, which have a total retail value of more than $\$ 1,000 . " 104$ Moreover, the NET Act creates criminal liability for the willful infringement of a copyright "for purposes of commercial advantage or private financial gain." 105

\section{The Digital Millennium Copyright Act}

Although these amendments were intended to improve and enlarge the protection afforded under the Copyright Act, the motion picture industry has rarely invoked the Copyright Act since the enactment of the NET Act in 1997. Instead, Hollywood studios have relied almost solely upon the DMCA in order to prosecute digital pirates. Heralded by many as the "most sweeping revision[] ever to the Copyright Act of 1976," ${ }^{, 106}$ the DMCA was enacted by Congress in the Fall of 1998 in an effort to provide "copyright owners of digital works, such as computer

\footnotetext{
102 Oross, supra note 13 , at 154.

${ }^{103}$ See id.; see also United States v. LaMacchia, 871 F. Supp. 535 (D. Mass. 1994) (in which a student who created a software piracy ring was found not to be liable for basic copyright infringement because of the absence of commercial motivation or financial gain).

${ }^{104} 17$ U.S.C. $\S 506(a)(2)(2000)$.

${ }^{105} 17$ U.S.C. $§ 506(a)(1)$ (2000). Under the NET Act, "financial gain" includes the "receipt, or expectation of receipt, of anything of value, including the receipt of other copyrighted works." Id.

${ }^{106}$ See David Nimmer, A Riff on Fair Use in the Digital Millennium Copyright Act, 148 U. Pa. L. Rev. 673,674 (2000).
} 
software and films on DVD, [a] 'reasonable assurance' of protection against [online] piracy .....107 Such an assurance would ensure the long-term viability of the Internet as an engine of economic growth. ${ }^{108}$ To this end, Title I of the DMCA makes it unlawful to circumvent any technological measure used by copyright owners to protect their digital works. ${ }^{109}$ Although there are numerous exceptions to this general prohibition, anyone held to be in violation of the DMCA's anti-circumvention provisions is subject to both civil and criminal liability. ${ }^{110}$

Title II of the DMCA, on the other hand, provides an Internet Service Provider ("ISP") with safe harbor from the unlawful activities of its users; that is, an entity will not be found liable for copyright infringement so long as it both qualifies as an ISP within the meaning of the DMCA and removes infringing material from its system once notice has been given that the material is infringing another's copyright. ${ }^{111}$

\section{Anti-Circumvention Provisions}

The anti-circumvention provisions of the DMCA make it unlawful for an individual to "circumvent a technological measure that effectively controls access to a [copyrighted] work ...." ${ }^{112}$ Moreover, the Act also prohibits an individual from assisting others in the circumvention of such "technological measure[s]." ${ }^{\text {"113 }}$ Section 1201(a)(2)(A), for example, provides that "[ n]o person shall ... traffic in any technology ... primarily designed or produced for the purpose of

\footnotetext{
${ }^{107}$ See Moore, supra note 79, at 1439; S. REP. No. 105-190, at 8 (1998).

${ }^{108}$ S. REP. NO. 105-190, at 8 (1998) (noting that the owners of digital works would be hesitant to make their works available to the public online because of the ease with which they might be illegally duplicated).

${ }^{109}$ See 17 U.S.C. $\S 1201$ (2000).

${ }^{110} 17$ U.S.C. $\S 1203$ (2000); 17 U.S.C. $§ 1204$ (2000).

${ }^{111} 17$ U.S.C. $\S 512(2000)$.

11217 U.S.C. $\S 1201$ (a) (2000).

${ }^{113} 17$ U.S.C. § 1201(a)(2) (2000); 17 U.S.C. § 1201(b)(1) (2000).
} 
circumventing a technological measure . ..."114 Section 1201(b)(1)(A) further provides that "[n]o person shall ... traffic in any technology ... primarily designed or produced for the purpose of circumventing protection afforded by a technological measure that effectively protects a right of a copyright owner under [the DMCA]." ${ }^{115}$ Although the language of these two provisions is similar, the protection afforded by each is distinct. Whereas the former is designed to protect access to a copyrighted work, the latter protects the traditional rights afforded to an owner under U.S. copyright law and is applicable only to those devices which are designed to circumvent the technological safeguards used for the protection of an owner's work.

Those found to be in violation of the DMCA's anti-circumvention provisions are subject to both civil and criminal penalties. ${ }^{116}$ Under 17 U.S.C. $\S 1203(b)(1)$, when a party's copyright protection system is circumvented, that injured party may seek an injunction "on such terms as [the court] deems reasonable to prevent or restrain" any further violations of the DMCA's anticircumvention provisions. ${ }^{117}$ Furthermore, the court may also "order the remedial modification or the destruction of any device or production involved in the violation ...."118 The relief provided under $\S 1203$, however, is not limited to that available at equity. ${ }^{119}$ Rather, $\S 1203(\mathrm{c})$ allows the court to award the injured party both actual and statutory damages. ${ }^{120}$ Actual damages available under $\S 1203(\mathrm{c})(2)$ include any "damages suffered by the party as a result of the violation, and any profits of the violator that are attributable to the violation and are not taken

\footnotetext{
${ }^{114} 17$ U.S.C. $\S 1201(\mathrm{a})(2)(\mathrm{A})(2000)$.

11517 U.S.C. $\S 1201(\mathrm{~b})(1)(\mathrm{A})(2000)$.

${ }^{116}$ See 17 U.S.C. $§ 1203$ (2000); 17 U.S.C. $\$ 1204$ (2000).

${ }^{117} 17$ U.S.C. $\S 1203(b)(1)(2000)$.

11817 U.S.C. $\S 1203(\mathrm{~b})(6)(2000)$.

${ }^{119}$ See 17 U.S.C. $\S 1203(\mathrm{c})(2000)$.

${ }^{120} 17$ U.S.C. $\S 1203(c)(2)(2000) ; 17$ U.S.C. $\S 1203(c)(3)(2000)$.
} 
into account in computing the actual damages." ${ }^{\prime 21}$ Statutory damages may be recovered in a "sum of not less than $\$ 200$ or more than $\$ 2,500$ per act of circumvention ...." ${ }^{122}$ Criminal penalties for first-time offenders include a fine of up to $\$ 500,000$ and/or imprisonment for no more than 5 years. ${ }^{123}$ Repeat offenders are not to be fined "more than $\$ 1,000,000$ or imprisoned for ... more than 10 years, or both ...."124

Despite its otherwise strict prohibition against the circumvention of copyright protection systems, the DMCA does allow for several fair use exceptions to its anti-circumvention provisions. ${ }^{125}$ Nonprofit libraries, archives, and educational institutions, for example, may "gain[] access to a commercially exploited copyrighted work" for the limited purpose of determining whether to acquire a legal copy of that work for their collection. ${ }^{126}$ The DMCA also exempts the state from its anti-circumvention provisions by authorizing "any lawfully authorized investigative, protective, information security, or intelligence activity" which might require the circumvention of a technology. ${ }^{127}$ Furthermore, circumvention is lawful for the limited purpose of either "identifying or analyzing those elements of [a computer] program that are necessary to achieve interoperability of an independently created computer"128 or "identify[ ing] and analyz[ing] flaws and vulnerabilities of encryption technologies applied to copyrighted

\footnotetext{
${ }^{121} 17$ U.S.C. $\S 1203(c)(2)(2000)$.

12217 U.S.C. $\$ 1203(\mathrm{c})(3)(2000)$.

${ }^{123} 17$ U.S.C. $\S 1204(\mathrm{a})(1)(2000)$.

${ }^{124} 17$ U.S.C. § 1204(a)(2) (2000).

${ }^{125}$ See 17 U.S.C. $\S 1201(\mathrm{c})-(\mathrm{k})(2000)$.

${ }^{126} 17$ U.S.C. $\S 1201(\mathrm{~d})(2000)$.

${ }^{127} 17$ U.S.C. $\$ 1201(\mathrm{e})$ (2000).

${ }^{128} 17$ U.S.C. $\S 1201(f)(1)(2000)$.
} 
works." ${ }^{129}$ This latter exception also requires, among other things, both that circumvention be "necessary to conduct ... encryption research" 130 and that "a good faith effort [be made] to obtain authorization before the circumvention."

\section{ISP Safe Harbor Provisions}

Whereas the anti-circumvention provisions of the DMCA provide copyright owners with additional recourse against digital pirates, $\S 512$ of the Act limits the liability of an ISP for the wrongdoings of its users. ${ }^{132}$ Before an entity can invoke the protection of the ISP safe harbor provision, however, it must first qualify as a "service provider" within the meaning of $\S 512$. A service provider includes any "entity offering the transmission, routing, or providing of connections for digital online communications, between or among points specified by a user, of material of the user's choosing, without modification to the content of the material as sent or received."133 In addition to qualifying as an ISP, an entity must also meet two additional "conditions for eligibility" before its liability under the DMCA can be limited by the ISP safe harbor. ${ }^{134}$ As set forth in $\S 512(\quad$ i), an ISP must “ adopt[] ... a policy that provides for the

${ }^{129} 17$ U.S.C. $\S 1201(\mathrm{~g})(1)$ (2000) (defining “encryption research”). The actual encryption research exception, however, is found at 17 U.S.C. $\S 1201(\mathrm{~g})(2)(2000)$.

${ }^{130} 17$ U.S.C. $\S 1201(\mathrm{~g})(2)(\mathrm{B})$.

${ }^{131} 17$ U.S.C. $\S 1201(\mathrm{~g})(2)(\mathrm{C})$.

132 See 17 U.S.C. $\$ 512(2000)$.

${ }^{133} 17$ U.S.C. $\S 512(\mathrm{k})(1)(A)$. Note that as used in other subsections of $\S 512$, however, the term "service provider" simply refers to "a provider of online services or network access, or the operator of facilities therefor...." 17 U.S.C. $\S 512(\mathrm{k})(1)(\mathrm{B})$.

13417 U.S.C. $\S 512(i)(1)$. 
termination ... of subscribers and account holders ... who are repeat infringers" of the DMCA, ${ }^{135}$ and must "accommodate[] and ... not interfere with standard technical measures."

Once an entity has qualified as a service provider and has met the additional requirements of $\S 512(\mathrm{i})$, it is eligible for immunity from any liability resulting from the storage of infringing material on its network or system. However, certain additional statutory conditions must be met. ${ }^{137}$ Under $\S 512(a)$, for example, an ISP is free from any liability resulting from "the provider's transmitting, routing, or providing connections for, material through a system or network controlled or operated by or for the service provider" ${ }^{\text {"138 }}$ only if the transmission was "initiated by or at the direction of a person other than the service provider."139 Section 512(b) further limits an ISP's liability for the "intermediate and temporary storage" system or network provided that, among other things, "the material is made available online by a person other than the service provider."141 Section 512(c) limits an ISP's liability for the "infringement of copyright by reason of the storage at the direction of a user of material that resides on a system or network controlled or operated by or for the service provider ...,142 only if the ISP both does not have knowledge of the material's infringing nature and "expeditiously"143

\footnotetext{
${ }^{135} 17$ U.S.C. § 512(i)(1)(A).

${ }^{136} 17$ U.S.C. § 512(i)(1)(B).

${ }^{137} 17$ U.S.C. $\$ 512(a)$.

${ }^{138} 17$ U.S.C. $\S 512(a),(c)$.

${ }^{139} 17$ U.S.C. $\S 512(\mathrm{a})(1)$. This provision contains additional statutory requirements.

${ }^{140} 17$ U.S.C. $\S 512(b)(1)$.

${ }^{141} 17$ U.S.C. $\S 512(\mathrm{~b})(1)(\mathrm{A})$.

${ }^{142} 17$ U.S.C. § 512(c)(1).

${ }^{143} 17$ U.S.C. $\S 512(\mathrm{c})(1)(\mathrm{A})(\mathrm{iii})$.
} 
removes the material from its system once notice of the claimed infringement is given pursuant to $\S 512(\mathrm{c})(3){ }^{144}$

In addition to the limitations on liability provided by $\S \S 512(\mathrm{a})-(\mathrm{c})$, later subsections provide further safe harbor to service providers. ${ }^{145}$ Section $512(\mathrm{~d})$, for example, limits an ISP's liability for infringement resulting "by reason of the provider referring or linking users to an online location containing infringing material or infringing activity [or] by using information location tools" "146 so long as it "does not receive a financial benefit directly attributable to the infringing activity ...."147 Section 512(e) limits the liability of a nonprofit educational institution for monetary damages when a faculty member or student of the institution uses Internet access provided by the institution in order to infringe another's copyright provided that, among other things, "the institution provides to all users of its system or network informational materials that accurately describe, and promote compliance with, the laws of the United States relating to copyright." 148 Section $512(\mathrm{~g})$ also provides that "a service provider shall not be liable to any person for any claim based on the service provider's good faith disabling of access to ... material ... claimed to be infringing ... regardless of whether the material or activity is ultimately determined to be infringing." 149

\footnotetext{
${ }^{144} 17$ U.S.C. $\S 512(\mathrm{c})(3)$.

${ }^{145}$ See 17 U.S.C. $\S 512(\mathrm{~d})-(\mathrm{e}),(\mathrm{g})$.

${ }^{146} 17$ U.S.C. $\S 512(d)$.

${ }^{147} 17$ U.S.C. $\S 512(d)(2)$. Other prerequisites to safe harbor are included in this subsection.

14817 U.S.C. $\S 512(\mathrm{e})(1)(\mathrm{C})$. Section 512(e) provides further requirements for limitation of liability.

149 17 U.S.C. $\S 512(\mathrm{~g})(1)(2000)$.
} 


\section{Effectively Addressing the Problem of Digital Piracy}

The NET Act and the DMCA were enacted by Congress with the intention that they would ensure the long-term economic viability of the Internet by providing copyright owners of digital works with "reasonable assurance" against digital piracy. ${ }^{150}$ Ostensibly, both the NET Act and the DMCA are sufficiently drafted to achieve this end. The civil and criminal penalties imposed by each would certainly seem to cause a digital pirate to think twice before unlawfully duplicating a motion picture and distributing it over the Internet. In practice, however, neither the NET Act nor the DMCA have deterred digital motion picture piracy. Indeed, the failures of the recording industry's recent anti-piracy campaign illustrate that digital piracy is simply too widespread to be adequately addressed at law. That being said, digital motion picture piracy is a problem that can be solved. Doing so, however, would require the motion picture studios to address the underlying motivations for digital piracy rather than relying on the recourse provided by the Copyright Act, the NET Act, and the DMCA.

\section{A. Lessons Learned from the Recording Industry}

Like the motion picture industry, the recording industry is losing billions of dollars in potential profits each year as the direct result of digital piracy. ${ }^{151}$ Initially, the recording industry sought to address the problem of digital piracy by filing suit against the peer-to-peer file sharing networks, such as Napster. ${ }^{152}$ Recently, however, the focus of the recording industry's antipiracy efforts has shifted away from the owners and operators of peer-to-peer file sharing

\footnotetext{
${ }^{150}$ S. Rep. No. 105-90, at 8 (1998); Moore, supra note 79, at 1439.

${ }^{151}$ See Anti-Piracy, RIAA, http://www.riaa.com/issues/piracy/default.asp (last visited Oct. 7, 2004) (on file with the Pittsburgh Journal of Technology Law and Policy).

${ }^{152}$ See A \& M Records, Inc. v. Napster, Inc., 239 F.3d 1004 (9 $9^{\text {th }}$ Cir. 2001), aff'd, 284 F.3d 1091 (9 $9^{\text {th }}$ Cir. 2002).
} 
networks and towards those using these networks to illegally download music. ${ }^{153}$ In September 2003, for example, the Recording Industry Association of America ("RIAA") filed suit against 231 individuals who it believed to be guilty of digital music piracy in jurisdictions throughout the United States. ${ }^{154}$ Encouraged by the mass-media attention produced by its first round of lawsuits, the RIAA has subsequently initiated two additional rounds of lawsuits; eighty-one individuals were sued in October 2003 and forty-one individuals were sued in December $2003 .{ }^{155}$ While the RIAA-initiated lawsuits have increased awareness of the illegality of pirating music over the Internet, it is unclear whether these actions have actually discouraged the popularity of digital music piracy.

As the recording industry's most recent campaign against digital piracy is in its infancy, the long-term results of its actions remain to be seen. The short-term results of the recording industry's efforts, however, have been mixed at best. Certain research indicates that the RIAAinitiated lawsuits have discouraged the use of peer-to-peer file sharing networks as a means by which to pirate music. ${ }^{156}$ According to a recent study by Nielsen NetRatings, for example, the number of Internet users accessing the popular peer-to-peer file sharing network Kazaa has steadily declined since the first round of lawsuits filed by the RIAA, falling from a high of 7

\footnotetext{
${ }^{153}$ See 12-Year-Old Settles Music Swap Lawsuit, CNN.com, Feb. 18, 2004, at http:/www.cnn.com/2003/TECH/internet/09/09/music.swap.settlement/ (last visited October 11, 2004); Benny Evangelista, Download Lawsuit Dismissed/RIAA Drops Claims That Grandmother Stole Online Music, San Francisco Chronicle, September 25, 2003, at http://sfgate.com/cgibin/article.cgi?file=/chronicle/archive/2003/09/25/BUGJC1TOD1.DTL (last visited October 11, 2004). 
million users per week during June 2003 to a low of 3.2 million users per week in November 2003. ${ }^{157}$ Conversely, other research indicates that the use of peer-to-peer file sharing networks by Internet users continues to increase despite the threat of legal action by the RIAA. ${ }^{158}$ According to Big Champagne, a market research and consulting firm which specializes in peerto-peer technology, the number of persons using Kazaa to access the Fastrack network has actually increased to an all-time high of 5.6 million simultaneous users in October 2003. ${ }^{159}$

While it may be unclear whether the RIAA-initiated lawsuits have successfully deterred digital pirates from using peer-to-peer networks to illegally download music, it is clear that the recording industry's most recent campaign has been a public relations disaster. ${ }^{160}$ The RIAA selected individuals against whom to file suit solely on the basis of the number of songs allegedly being offered for download on their personal computers. ${ }^{161}$ For example, the first of the initial 261 individuals sued by the RIAA was a 12 -year-old girl. ${ }^{162}$ News of a multi-billiondollar-a-year industry suing children did little to create sympathy with the general public. Even more egregious was a lawsuit filed by the RIAA against a 65 -year-old grandmother. ${ }^{163} \mathrm{~A}$

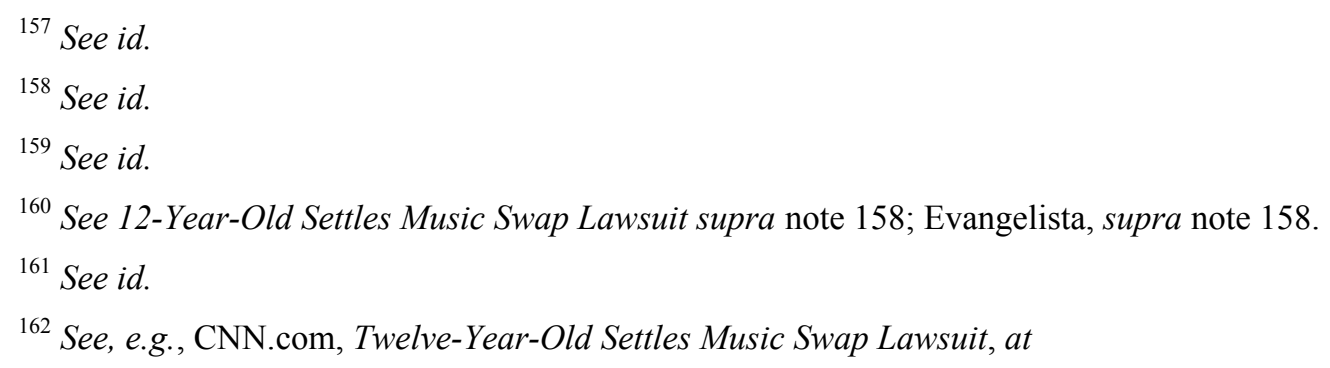

${ }^{163}$ See SFGate.Com, Download Lawsuit Dismissed/RIAA Drops Claims That Grandmother Stole Online Music (last visited July 23, 2004) <http://sfagate.com/cgi-bin/article.cgi?file=/c/a/2002/09/25BUGJC1TO2D1.DTl>. See SFGate.Com, Download Lawsuit Dismissed/RIAA Drops Claims That Grandmother Stole Online Music, available at $\mathrm{http} / /$ sfagate.com/cgi-bin/article.cgi?file=/c/a/2002/09/25BUGJC1TO2D1.DTl (last visited Oct.12, 2004). 
sculptor and retired educator by trade, the grandmother claimed that she knew little about peerto-peer file sharing until a man pounded on her door late one evening and served her with notice of the action that RIAA had filed against her. ${ }^{164}$ The RIAA included the grandmother among its initial class of 261 defendants because she was allegedly offering more than 2,000 songs for download over Kazaa, including the popular song 'I'm a Thug' by hip-hop artist TrickDaddy. ${ }^{165}$ The motion picture industry would do well to learn from such public relations gaffes.

\section{B. Proposed Solutions}

Even if the RIAA's campaign does substantially deter the spread of digital music piracy, it will come at a high cost; not only has the recording industry faced enormous legal fees, it has also lost profits as a result of consumer alienation. In light of these costs, it seems unlikely that digital motion picture piracy will be effectively resolved by relying on the protections of United States copyright law. This does not mean, however, that the problem of digital motion picture piracy is unsolvable. The results garnered by the RIAA's recent anti-piracy initiative simply illustrate that a more creative approach is needed to deter digital piracy. However, as demonstrated by the proposed solutions offered on the following pages, there is no single way in which to eliminate digital piracy. Instead, motion picture studios must discourage digital piracy in a myriad of different ways. Only by eliminating the psychological need and the technical ability of digital pirates to duplicate a film and distribute it to others over the Internet will the problem of digital motion picture piracy be resolved.

\footnotetext{
${ }^{164} I d$.

${ }^{165} \mathrm{Id}$.
} 


\section{More Selective Enforcement of United States Copyright Law}

As RIAA's approach to fighting digital piracy has demonstrated, invoking the protections afforded by United States copyright law against members of an otherwise nebulous class of persons is not without its difficulties. That said, the motion picture industry should not entirely dismiss the idea of pursuing a similar approach against digital motion picture pirates. The motion picture industry should instead learn from the mistakes made by the RIAA. For example, when enforcing its rights under the DMCA, the motion picture industry should strive to protect its copyrights without alienating its customers. One way to avoid such consumer alienation is to be more selective than the RIAA had been in who it will sue under the DMCA. Although the RIAA limited its litigation to those individuals with large quantities of pirated music files available for download on their personal computers, which has resulted in numerous lawsuits in nearly every jurisdiction. Such a piecemeal approach does little to deter digital piracy. Arguably, a better approach would be to target a few high-profile pirates and concentrate the industry's anti-piracy resources on the successful prosecution of these individuals.

\section{Incentives to Theatre Employees}

Another way to prevent digital motion picture piracy is to enlist the help of local motion picture theatre employees. In California, for instance, an industry trade group is now offering a cash reward of up to $\$ 500$ to theatre employees who report moviegoers using camcorders or other recording devices to make illicit copies of the film. ${ }^{166}$ Such an incentive-based approach, if successful, promises to significantly decrease the number of pirated new releases available on the

\footnotetext{
${ }^{166}$ See CNN.Com, Piracy Arrest at 'Spider-Man 2' Opening Night (last visited July 2, 2004) at http://www.cnn.com/2004/SHOWBIZ/Movies/06/30/spiderman.arrest.ap/.
} 
Internet. ${ }^{167}$ Although the initiative has just begun, the motion picture industry is already seeing results. For example, a California teenager was recently arrested at a midnight showing of "Spider-Man 2" after a projectionist spotted him using a camcorder to record the new release. ${ }^{168}$ By stopping the teenager from making his illegal recording, the projectionist prevented a copy of "Spider-Man 2" from being made available for download on the Internet to countless potential paying theatre-goers.

\section{Alternative Release Methods}

The motion picture industry might also discourage digital piracy by developing low-cost alternatives to the traditional way in which motion pictures are released to the public. Assuming that the popularity of digital piracy is driven, at least in part, by the convenience of downloading a motion picture from the Internet and viewing it whenever one chooses, the need to resort to digital piracy might be eliminated if the motion picture industry itself was to offer a comparably convenient, but legal, method of distribution. For example, iTunes, an online music service, allows Internet users to download MP3 files for a small transactional fee. ${ }^{169}$ The motion picture industry could easily offer a similar service which would allow Internet users to download DivX or MPEG quality motion pictures for either transactional or monthly subscription fees. Moreover, the popularity of such a service could grow even beyond that of iTunes if the motion picture industry were to distribute previously released motion pictures, as well as high-quality new releases. Not only would such a service eliminate the popularity of peer-to-peer networks as

\footnotetext{
${ }^{167}$ See id. Ninety-two percent of all pirated motion pictures, whether traded online or sold on street corners, are the result of moviegoers using a camcorder or other recording devices to tape a public showing of a motion picture.

${ }^{168}$ See id.

${ }^{169}$ Apple's iTunes digital music service, at http://www.apple.com/itunes/.
} 
a means of downloading the latest theatrical releases, it would also increase total profits for the motion picture industry.

\section{Educational Initiatives}

Before the threat posed by digital motion picture piracy can be eliminated, the public must first understand the ills of such unlawful conduct. Research suggests that most people using peer-to-peer file sharing networks to download motion picture files onto their personal computers do not realize that they are committing a crime. ${ }^{170}$ While ignorance of the law is no excuse, the motion picture industry's approach of suing millions of Americans who unwittingly pirate motion pictures is neither cost-efficient nor effective. Educating the public as to the illegality of downloading motion pictures is a considerably easier and more cost-efficient means of deterring digital motion picture piracy. To some extent, the MPAA has already begun this process by placing advertisements in newspapers and consumer magazines across the country which "explain why movie piracy is illegal, how it impacts jobs and the economy and the consequences of engaging in illegal trafficking."171 In addition, the MPAA is running antipiracy advertisements prior to screenings of motion pictures in theatres across the country. ${ }^{172}$ Although such measures constitute an important first step in educating the public, to be truly effective these advertisements must be more widespread and must target those most likely to digitally pirate a motion picture - teenagers.

\footnotetext{
${ }^{170}$ See KOMO TV, MPAA Launches New Phase of Aggressive Education Campaign Against Movie Piracy at http://ww3.komotv.com/global/storay.asp?s=1942518 (last visited July 13, 2004).

${ }^{171}$ See id.

${ }^{172}$ See id.
} 


\section{Digital Countermeasures}

Digital piracy might also be deterred by making the search for pirated motion pictures on the Internet more difficult through the use of "digital countermeasures." The advent of peer-topeer technology has simplified the once nearly impossible task of locating a specific motion picture file in the vastness of cyberspace. Digital countermeasures, however, can recreate the difficulty of this task, thereby eliminating the use of peer-to-peer technology as a viable means of digital motion picture piracy. For example, a motion picture studio could flood a peer-to-peer network with files whose names correspond with the titles of motion pictures but whose content is actually something else. As a result, digital pirates would likely download countless "dummy" files before successfully downloading the actual file which they were seeking. Increasing the time it takes to successfully download a motion picture file is arguably the best deterrent against digital motion picture piracy. Complicating the use of peer-to-peer networks in this way could greatly reduce the attractiveness of digital piracy.

\section{6. $\quad$ More Incentives to Purchase Its Product}

The motion picture industry might further discourage digital piracy by providing consumers with greater incentives to purchase either a DVD or a ticket to a local theatre rather than downloading a motion picture from the Internet. For instance, additional features could be included on a motion picture DVD. Additional features would become as important a part of the home-viewing experience as is the motion picture itself. Although additional features have become common to many DVDs, there are still some motion pictures that are released in DVD

format without such features. Moreover, many DVDs which do include additional features could use some significant improvement, both in quality and entertainment value.

\section{Conclusion}


Motion picture studios are currently losing billions of dollars in profits each year as the result of digital piracy. As the process of duplicating a motion picture and distributing it to others over the Internet becomes even easier, these studios stand to lose billions of dollars more unless digital piracy can be stopped. Fortunately for the motion picture industry, the problem of digital piracy is one which can be resolved. The answer, however, does not lie in the Copyright Act, the NET Act, or the DMCA. Indeed, digital piracy is simply too widespread of a problem to be addressed at law. In order to effectively address the problem of digital piracy, the motion picture industry must eliminate the psychological need and the technological ability of digital pirates to duplicate a motion picture and distribute it to others over the Internet. There is no one way to achieve this end. Rather, the motion picture industry should adopt a variety of approaches aimed at discouraging digital piracy, including selectively enforcing the copyright laws, providing incentives to theatre employees who report acts of digital piracy, providing movie-goers with alternatives to the traditional DVD and theatrical release, educating the public on the ills of digital piracy, utilizing "digital countermeasures," and producing a higher-quality product. 